\title{
UNA MIRADA DECISIVA. TENSIONES ENTRE LIBERTAD Y EMANCIPACIÓN FEMENINA EN LA SERIE IDILIO DE GRETE STERN
}

\author{
MARÍA LAURA Rosa \\ Universidad de Buenos Aires
}

El presente artículo busca analizar algunos fotomontajes realizados por la fotógrafa alemana
radicada en Argentina Grete Stern (Wuppertal, 1904- Buenos Aires, 1999) para la sección "El
psicoanálisis le ayudará" de la revista Idilio, llevados a cabo entre 1948 y 1951. Éstos reflejaron
la crisis de la mujer como "ángel del hogar", patrón característico del repliegue hacia lo
doméstico que sufrió el género luego de la Segunda Guerra Mundial. Me acercaré a dichos
trabajos desde la premisa que las obras de Stern exponen los reclamos de libertad de la Mujer
Nueva de principios del siglo Xx en Argentina. Seleccionaré un grupo de fotomontajes que
presentan, a mi entender, ciertas tensiones manifestadas por la reacción patriarcal contra las
ansias de libertad y realización del propio deseo de las mujeres modernas. Si bien la crítica se ha
detenido en Idilio para analizar los cambios acaecidos sobre la familia nuclear, el debate estético
y su impacto en los medios masivos de comunicación o el impacto de las teorías psicoanalíticas
en los fotomontajes de Stern, propongo partir del supuesto que la fotógrafa construyó una
interpretación propia de aquellos relatos en la que intervino su particular mirada sobre la
condición femenina, la que contrasta con la interpretación psicoanalítica del dúo Germani-
Butelman. Esta última auspició de moderadora - frente a Stern- de las libertades femeninas
en pro de una domesticidad que peligraba.

PALABRAS CLAVE: Arte contemporáneo, arte argentino, teoría feminista del arte, estudios de género, fotografía argentina.

A Decisive Look. Tensions Between Freedom and Female Emancipation in the Idyll Series by Grete Stern

This paper analyzes some of the collages made by the Argentinian-based German photographer Grete Stern (Wuppertal, 1904-Buenos Aires, 1999) for the section "Psychoanalysis will help you" in Idilio magazine, published between 1948 and 1951. The photomontages reflect the crisis of the notion of "angel in the house", which meant the retreat of women to the domestic sphere after World War II. I approach these works as expressions of the claim to freedom posed by the New Woman of the early twentieth-century in Argentina. I have selected a group of photomontages that express, in my opinion, the tension caused by the patriarchal reaction against modern women's desire for freedom and self-development. Critical readings of the Idilio series have focused, for the most part, on the changes in the family structure, on the aesthetic debate and its impact on the mass media, and even on the influence of psychoanalytical theories on Stern's photomontages. However, I base my reading on the

Rosa, María Laura (2014), "Una mirada decisiva. Tensiones entre libertad y emancipación femenina en la serie Idilio de Grete Stern", Lectora, 20: 191-209. ISSN: 1136-5781 
assumption that the photographer developed her own interpretation of those stories, posing her unique gaze on women's position in society, in contrast to the psychoanalytic interpretation by Germani-Butelman who, against Stern's work, tried to moderate women's liberties in favor of a declining domesticity.

KEY WORDS: Contemporary art, Argentinean art, feminist art theory, gender studies, Argentinean photography.

\section{Contexto político y cultural del “ángel del hogar”}

Durante la década de 1930 la Argentina afrontó una serie de cambios políticos y sociales que dispararon un proceso de aguda modernización. Dicha situación impactó sobre el modelo de familia nuclear, cristalizado durante la década de 1920 gracias a los discursos del estado, la iglesia católica y la corporación médica. El golpe de Estado de 1930 protagonizado por el general Uriburu reflejó la polarización de la sociedad argentina entre conservadores y liberales, así señala Dora Barrancos: "La restauración moral abarcaba mucho más que los sentidos habituales otorgados a las cuestiones públicas. Los conservadores varones y mujeres, estaban asustados con las crecientes marcas de autonomía que mostraban las mujeres debido al contacto con géneros culturales contaminantes" (Barrancos, 2007: 156).

Dicha "contaminación" refiere a la creciente industria cinematográfica local, que influida por el cine de Hollywood, reafirmó los estándares de género, desde la femme fatale a la mujer doméstica. En ese sentido, el aumento de la industria editorial que trajo el auge de las revistas femeninas acompañó este proceso de apoyo al modelo nuclear heteronormativo. Sin embargo, y en paralelo a las industrias cinematográfica y editorial, no debemos olvidar que "el primer medio masivo de comunicación social — la radio_- contribuirá a homogeneizar hacia abajo, si no las estructuras familiares, al menos los estereotipos que se proponían como modelo para el conjunto social”. (Míguez, 1999: 42)

Sin embargo, la década de 1930 vio incrementar el reclamo de algunas mujeres por sus derechos de ciudadanía a la vez que se reforzaba el modelo de familia nuclear. Así señala Marcela Nari:

La mujer doméstica fue una de las transformaciones más impactantes, en parte producida, en parte incorporada, en el nuevo modelo de familia moderna. Una esposa y una madre, doméstica y domesticada, que intentaba conjurar los temores heredados de la femineidad, disciplinar las prácticas sociales de las mujeres y familiares, y que aportaba una esperanza de regeneración a la raza, la sociedad, la nación. Esto producía y daba por supuesto una reformulación de las relaciones familiares: el eje clásico de la familia patriarcal (padre-hijo) se desviaba al inalienable binomio "natural” madre-niño. (Nari, 2004: 70) 
$\mathrm{Si}$ bien las dos primeras décadas del siglo pasado fueron testigos del surgimiento de las primeras agrupaciones feministas argentinas -Centro Feminista de 1905, Liga Feminista Nacional de la República Argentina de 1905, Asociación pro Derechos de la Mujer de 1918- en su mayoría vinculadas al Partido Socialista, la década de 1930 fue el eslabón necesario para la aprobación de la ley 13.010 sancionada en 1947, por la que lucharon distintas agrupaciones feministas y no feministas. Por entonces la Asociación Argentina por el Sufragio Femenino — fundada por Carmela Horne - y la Unión Argentina de Mujeres cuya presidenta era Victoria Ocampo y su vicepresidenta María Rosa Oliver, ambas escritoras-, desarrollaron importantes campañas.

A la vez que las mujeres reclamaban sus derechos, también se manifestaron contrarias a las guerras - Guerra Civil Española y Segunda Guerra Mundial-, vinculando al feminismo con el pacifismo. Al respecto señala Marcela Nari:

Con una amplia participación de mujeres comunistas, en 1937 se creó el Comité Argentino de Mujeres Pro Huérfanos Españoles y, en 1941, la Junta de la Vitoria, una agrupación femenina de solidaridad con los aliados. Esta vinculación con mujeres comunistas profundizó en sectores nacionalistas y católicos la percepción del feminismo como ideología extranjera, extraña a la esencia nacional, y disolvente del orden natural-divino, percepción que el peronismo heredaría. (Nari, 2000: 214)

De ahí el rechazo de Eva Perón hacia las feministas, a quienes denigraba señalándolas como "mujeres cuya primera vocación debió ser indudablemente la de hombres. (...) Parecían estar orientadas por el despecho de no haber nacido hombres más que por el orgullo de ser mujeres" (Perón, 1951: 47). Fue por ello que al finalizar la década de 1940 asistimos a la conquista del derecho al voto femenino pero sin cuestionar el rol "natural" de la mujer, la maternidad, y sus extensiones permitidas en el ámbito laboral: maestra y enfermera. ${ }^{1}$

Sobre este contexto, signado por las contradicciones, debemos tener en cuenta la expansión del psicoanálisis en los centros urbanos de la Argentina, el cual se divulgó a través de la cultura de masas gracias a la incorporación del consultorio del psicoanalista o consultorio epistolar en varias publicaciones periódicas. Así indica Mariano Ben Plotkin:

El final de la década de 1920 y el comienzo de la siguiente fue un período de difusión del psicoanálisis en la cultura argentina. La crisis del

\footnotetext{
${ }^{1}$ Señala Marcela Nari: "A pesar de las diferencias que las feministas se empeñaron en destacar con el discurso político del peronismo hacia las mujeres y los esfuerzos de éste y de Eva Perón por cortar con el pasado, el argumento de la maternidad fue determinante para el sufragio." (Nari, 2000: 216-217)
} 
positivismo y en particular del paradigma de la degeneración hereditaria en psiquiatría facilitó la introducción del psicoanálisis en los circuitos médicos e intelectuales. Los cambios sociales y culturales volvieron a la gente más receptiva a esta novedad. La transformación de las costumbres, un renovado interés por la sexología y la difusión del saber en la población general despertaron el interés por las versiones populares de las teorías freudianas, como lo atestiguan la columna de Freudiano y los catálogos de las editoriales de interés general. (Ben Plotkin, 2003: 65)

Si en las primeras décadas del 1900 la Argentina contaba con la figura del médico consejero quien, desde los medios de comunicación, buscó la prevención de las enfermedades dentro de los ideales del higienismo, durante las décadas de 1930 y 1940 se contaba con el psicoanalista, quien recibía y orientaba el discurso de la intimidad transmitido por el/la lector/a. Señala Hugo Vezzetti: "Paradójicamente, las peripecias de la intimidad se revelaban (y, de algún modo, se legitimaban) a través de esa exposición pública que ponía en evidencia que en la confesión también operaba una construcción social o, en todo caso, que en ella se combinaban la construcción social y la individualización, la uniformidad y la singularidad personal" (Vezzetti, 1999: 175).

En 1942 se fundó en Buenos Aires la Asociación Psicoanalítica Argentina (APA), gracias a las gestiones del emigrado español Ángel Garma, en donde se desarrollaron reuniones y conferencias. En este contexto las publicaciones sobre psicoanálisis aumentaron y con ellas algunas revistan conformaron secciones dedicadas a las consultas de sus lectores/as. Dicha situación se amalgamó a los cambios demográficos - auge inmigratorio que reverdeció en la posguerra- y culturales. Ambos confluyeron en la modernización de Buenos Aires a la vez que impactaron sobre los roles de género.

Sin embargo, el binomio psicoanálisis-arte fue distante en el contexto de las vanguardias artísticas del país, a diferencia de lo acontecido en Europa y Estados Unidos. La fuerte presencia del realismo social durante la década de 1930, dada la prédica del muralismo mexicano y en particular la del artista David Alfaro Siqueiros, quien visitó la Argentina en 1934, eclipsó el desarrollo de esta corriente (Constantín \& Weschler, 2005: 100- ss.). A su vez, el planteamiento concretista de la década de 1940, con el que se vinculó Grete Stern desde su origen, planteó un lenguaje basado en la convicción de "no crear sino inventar", estableciendo a la razón por encima del mundo de la imaginación y de la oniria. Ante lo dicho, nuestro surrealismo se caracterizó por tener un arribo un tanto tardío y segmentado de algunas individualidades. (Ben Plotkin, 2003: 56-57) 


\section{Entre la visibilidad y el ocultamiento de las molestias femeninas}

Cuando en 1948 la editorial Abril presentó la revista Idilio, que ostentaba ser juvenil y femenina gracias a la novedad de incluir por primera vez en el país relatos sentimentales en forma de fotonovelas, no fue extraño que en ella existiera una sección dedicada al consejero psicoanalista. Aquel público femenino que acudía con sus epístolas al consejo del especialista estaba atravesado por el amor romántico, construcción que efectivizaba el ideal doméstico, según señala Vezzetti:

parecía vivir sólo en la esfera de los afectos y, sobre todo, de la magia y la aventura del amor; en ese sentido la revista parecía responder, sobre todo, a esa dimensión imaginaria (compensatoria si se quiere) en la que casi no había lugar para las obligaciones. Pero, al mismo tiempo, expandía y profundizaba esa imagen de un ser entregado a la fuerza de sus emociones. En la hiperafectividad, en su condición básicamente sentimental (que no se opone a cierta inteligencia basada en la intuición y el instinto) radicaría, a la vez, su debilidad y su fuerza; en todo caso, su naturaleza esencialmente diferente al varón. (Vezzetti, 1999: 186-187)

La sección El psicoanálisis te ayudará, que a partir del número diez se llamó El psicoanálisis le ayudará, estuvo integrada por dos intelectuales y una fotógrafa, quienes trabajaron conjuntamente entre 1948 y 1951. El sello personal que dejaron en dicha columna fue motivo de tesis, análisis y revisiones durante las últimas décadas tanto en Argentina, como en Brasil y España, ${ }^{2}$ países interesados particularmente por la obra de Grete Stern para Idilio. Richard Rest fue el seudónimo empleado por Gino Germani y Enrique Butelman ${ }^{3}$ para los comentarios y consejos a las lectoras. Al respecto, Grete Stern volcaba en imágenes aquellas epístolas, empleando el lenguaje del fotomontaje, conocido por ella en sus años de formación en Alemania, su país natal.

\footnotetext{
2 Véase Jorge Gullco, "Sencillamente, Grete Stern", Grete Stern. Fotografía 1927-1980 (Buenos Aires, 1980); Luis Príamo y Matteo Goretti (eds.), Sueños. Fotomontajes de Grete Stern. Serie completa. Edición de la obra impresa en la revista Idilio (1948-1951) (Buenos Aires, 2012); V.V.A.A., Os sonhos de Grete Stern, (São Paulo, 2009); V.V.A.A., Grete Stern (Valencia, 1995).

${ }^{3}$ Gino Germani (Roma 1911-Nápoles 1979), sociólogo italiano que se estableció en Argentina en 1934, fundador de las carreras de sociología y psicología en la Universidad de Buenos Aires. Enrique Butelman (Buenos Aires 1917-1990), filósofo y psicólogo, destacado docente universitario que creará en 1945, junto a Jaime Bernstein, la Editorial Paidós.
} 

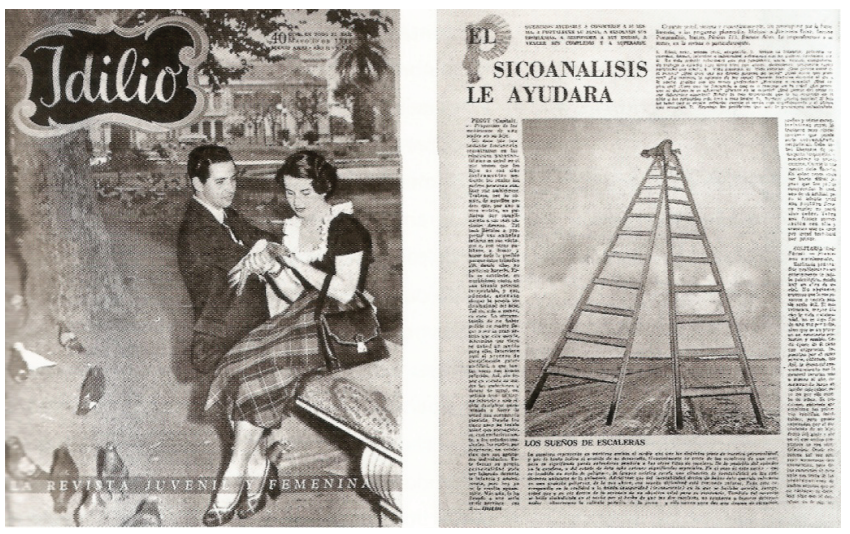

Idilio, n²5, 10 de mayo de 1949, tapa y pág. 2.

Stern y su marido, el fotógrafo Horacio Coppola, se habían radicado en la Argentina en 1935. La fotógrafa se dedicó a los géneros del retrato y del paisaje, fotografiando a intelectuales de Buenos Aires y a la arquitectura modernista de la ciudad. Asimismo trabajó para editoriales como Losada, Emecé, Editorial Universitaria, entre otras. Desde 1956 hasta 1970, se desempeñó en el departamento de fotografía del Museo Nacional de Bellas Artes, del que fue fundadora.

Grete Stern fue una de las destacadas fotógrafas alemanas que por esos años recibía la Argentina; cabe recordar a Annemarie Heinrich y el paso fugaz de Gisele Freund por el país. Stern se había formado con el maestro Walter Peterhans quien integró la Bauhaus de Dessau. En los cursos que Peterhans dictaba en su taller, Stern conoció a la fotógrafa Ellen Auerbach. Ambas estudiaron en la Bauhaus a la vez que llevaban su propio estudio de fotografía publicitaria, el recordado ringl+pit. La fotógrafa se movió en un círculo marcado por la efervescencia de las vanguardias artísticas alemanas, y allí conoció al dadaísmo y su estética del fotomontaje como crítica política (Gullco, 1980: s.p.). En 1934, el ascenso de Hitler al poder llevó a las amigas y sus respectivas parejas al exilio en Londres. Finalmente Coppola y Stern se radicaron al año siguiente en la Argentina.

Grete Stern representó a la Nueva Mujer (Neue Frau en alemán), sencilla pero con un aspecto muy diferente a las argentinas de entonces. Así recordaba su hija Silvia:

Cuando ella llegó acá, era como un bicho raro. Imagínate, venía de los círculos de Berlín y Londres donde las mujeres eran mucho más libres, 
se vestían como querían. Mi madre se instaló en Ramos Mejía ${ }^{4}$ en los 40 y caminaba por la calle tan tranquila en pantalones. María Elena Walsh todavía se acuerda del escándalo que provocaba. Ella iba a veces con el pelo a la garçon, tuvo épocas en que se pintaba mucho y otras nada, casi siempre con el pucho ${ }^{5}$ en la boca. Un estilo completamente fuera de los cánones aceptados en esa época. (...) Pero mi mamá no se sentía una transgresora, ella pensaba que tenía derecho a hacer lo que se le diera la real gana. No registraba toda la incomodidad o sorpresa que despertaban sus actitudes. (Soto, 2000: s.p.)

No es de extrañar que esta mujer, que tenía una actitud individual y libertaria frente a la vida, reflejara en sus trabajos de Idilio su experiencia personal y su propia perspectiva de género, los que claramente rompieron con muchos de los estereotipos limitantes propios de aquel entonces. ${ }^{6}$ Es por ello que, si bien la crítica se ha detenido en analizar la serie de fotomontajes para Idilio destacando los cambios acaecidos sobre la familia nuclear (Sánchez, 2006), el debate estético y su impacto en los medios masivos de comunicación (Bertúa, 2008; Id., 2010; Id., 2012), la idea de una ficción sin autor (Antelo, 2008), el impacto de las teorías psicoanalíticas en los comentarios de Rest y en los fotomontajes de Stern (Foster, 2001; Fabris, 2009; Frayze-Pereira, 2009; Soria, 2010); propongo avanzar en la interpretación de algunos fotomontajes deteniéndonos en cómo estos dan luz al mundo de la intimidad — lo que debía quedar oculto, lo personal-, los roles asignados a los sexos, la inmanencia del trabajo doméstico, la procreación como condición sine qua non de lo femenino.

Dado que no contamos con las cartas enviadas por las lectoras de $\mathrm{Idilio}^{7}$ para contrastar con las interpretaciones de Rest ni con las descripciones que dispararon las obras de Stern, me propongo analizar algunos fotomontajes partiendo de la idea de que la fotógrafa construyó una interpretación propia de aquellos relatos, donde intervino su particular mirada sobre la condición femenina. Para tal fin me valdré de diferentes pensadoras feministas que han aportado al campo teórico del arte.

\footnotetext{
${ }^{4}$ Localidad de la provincia de Buenos Aires.

${ }^{5}$ Cigarrillo en lenguaje coloquial.

${ }^{6}$ En comunicación personal con su biógrafo, Luis Príamo, éste señala: "Lo que hubo, por supuesto, fue una influencia evidente del espíritu feminista [habla de las influencias de Stern sobre su hija Silvia] implícito en la conducta de vida de Grete, en los años veinte y treinta nadie hablaba de feminismo, pero es evidente que Grete era una protofeminista hecha y derecha, aunque nunca fue militante de nada". Comunicación personal con Luis Príamo, 17/01/2011.

${ }^{7}$ Podemos pensar que esto se debe a que la misma editorial habría tomado la medida de destruir las cartas con el fin de proteger la información privada de las lectoras y así evitar cualquier difusión de lo allí expuesto.
} 
Teresa de Lauretis en su texto La tecnología del género enuncia el concepto fuera de campo, que da cuenta del

movimiento existente entre el espacio discursivo (representado) de las posiciones que nos ofrecen los discursos hegemónicos y el fuera de campo, el otro lugar de estos discursos: esos otros espacios discursivos y sociales que existen, desde que las prácticas feministas los ha (re)construido, al margen o "entre líneas" de los discursos hegemónicos y en los intersticios de las instituciones, en las contra-prácticas y en nuevas formas de relaciones sociales. (De Lauretis, 1999: 63)

En ese sentido, Stern representó en sus fotomontajes el espacio discursivo crítico al rol impuesto para la feminidad, el cual aparecía fortalecido por el mercado de revistas femeninas del período y en cierta manera, dada la moderación del tono y el sentimentalismo del mensaje, aceptado y difundido por el consejero Richard Rest. Podemos ver cómo desde dentro del sistema hegemónico, esos fotomontajes reunieron una fuerte crítica al patrón doméstico, y por tanto, se hicieron eco de voces con las que hoy no contamos - las de las mismas lectoras relatando sus molestias-. ¿Por qué no pensar que Stern, mujer culta e inteligente, se valió de la palabra de aquellas mujeres para concentrar en las imágenes las críticas al sistema sexo-género?

Desde el punto de vista técnico, no es casualidad que Stern eligiera el lenguaje del fotomontaje para representar sueños, dado que la yuxtaposición y condensación, así como los cambios de escala, se acercaban más exactamente al mundo de la oniria. Así señala Brandon Taylor, aludiendo a las reflexiones sobre el cubismo y el surrealismo del lingüista Jakobson:

Jakobson se esforzaba por señalar que en el análisis de los sueños de Freud, la condensación (propia de la sinécdoque) y la sustitución (que lo es de la metonimia) parecen predominar sobre la identificación y simbolización (características de las metáforas) (...) Históricamente, el collage se había transformado a finales de los años veinte en una herramienta de agitación (Heartfield), de participación democrática (Klutsis) y de publicidad capitalista (por doquier) en la que ambas modalidades también están combinadas de forma muy compleja. (Taylor, 2009: 20)

A los artistas varones citados por Taylor, debemos agregar a la alemana Hannah Höch (1889-1978), una de las referentes fundamentales a la hora de denunciar los estereotipos femeninos de la década de 1920. Si bien no podemos asegurarlo, es posible que Grete Stern haya conocidos sus trabajos ya que contaba con una rica biblioteca, de la que dieron cuenta los artistas que integraron el grupo Arte Concreto Invención y Madí, quienes acostumbraban reunirse en su 
casa del barrio de Ramos Mejía (Rossi, 2012: 12-16). En una conferencia que dio en 1986 en el Foto Club Argentino Stern indicó:

No fueron los fotógrafos los primeros que hicieron de este juego con las fotografías un medio gráfico mundialmente reconocido, sino los artistas plásticos que integraban los movimientos Dadá y surrealismo. Ellos descubrieron en la fotografía un elemento nuevo y distinto para la realización de sus composiciones, en combinación con el dibujo y la pintura. (Stern, 2012: 31)

Respecto a la selección de fotomontajes de Stern, comenzaré con el llamado Los sueños vegetales, publicado en Idilio $\mathrm{n}^{\circ} 13$ del 18 de enero de 1949, el cual la autora nombró Sin título.

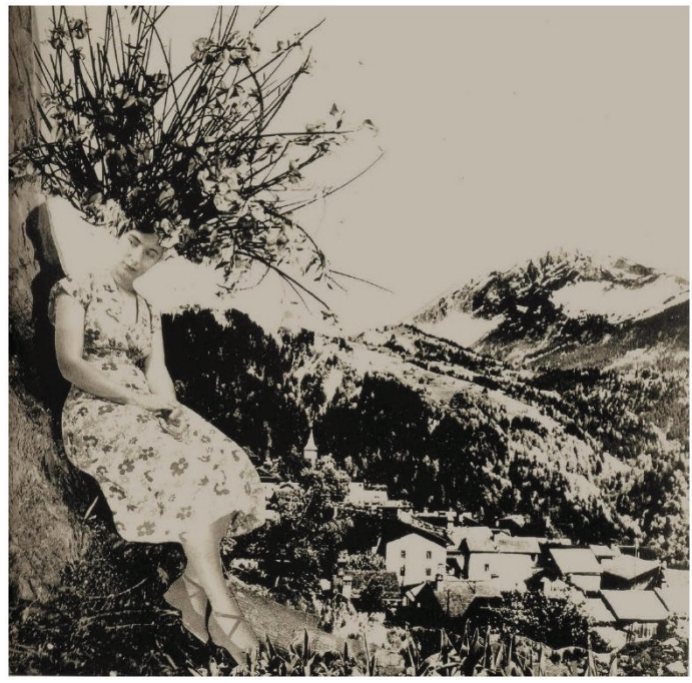

Los sueños vegetales, Idilio $\mathrm{n}^{\circ} 13,18$ de enero de 1949.

Allí observamos a una mujer joven sentada a los pies de un árbol. Detrás de ella hay un paisaje apacible. Su mirada oblicua se pierde hacia un lateral de la fotografía sin dirigirse hacia al/la espectador/a. El vestido floreado le pronuncia la cintura. El rostro pensativo y meditabundo impacta repentinamente sobre nuestra mirada al observar que por cabello tiene una enorme enramada, brotada de flores, que crecen hacia el cielo. El pelo femenino, objeto de seducción para el varón, aquí se transforma - podríamos pensar- en símbolo de la banalidad o superficialidad de la mujer. Sin embargo el comentario de Rest señalaba:

Los vegetales en general simbolizan aquello que se arraiga en la más oscura profundidad de la conciencia y crece de modo tranquilo y 
natural; al mismo tiempo lo vegetal es un símbolo exquisitamente femenino. Estas dos ligeras indicaciones bastan para interpretar el extraño sueño aquí representado. Lo tuvo repetidas veces esta jovencita y constituyó el anuncio a la vez del tranquilo despertar y del crecimiento de su alma, que la iba transformando de una niña en una mujer, en pleno florecer de sus personalidades anímicas. La escena primaveral que aparece en su sueño manifiesta otra indicación que se relaciona con el proceso psíquico. (Príamo \& Goretti, 2012: 116)

Contrariamente a esta interpretación salvaje, Stern muestra a una mujer tan estática como el árbol en donde se apoya; de hecho sus pies parecen acompañar a las raíces y al tronco en su ascenso. Más que una mujer que irradia energía, podemos ver a un ser pasivo sobre cuya cabeza las flores crecen. Stern parece plantear la cuestión opresiva de la naturaleza como destino de la mujer, que va ligada a su función reproductora. En su obra la mujer está sobre el árbol y forma parte de éste con su copa florida a modo de testa. También podríamos pensar que juega el rol de guardiana. Sin embargo, no parece haber nada más allá de esa función natural. Ella da la espalda al poblado que está a los pies de la ladera. No se insinúa futuro en él para ella.

Con cierta ironía, Stern deja percibir el destino de toda jovencita. Sobre el cielo, única zona vacía de la obra, se recorta la frondosa cabellera de la mujer, la que se equilibra compositivamente con el paisaje. Esa lateralidad de la figura sobre el árbol deja a la vista el corazón de la vida pública del vecindario de la ladera, a donde ella no aparenta pertenecer. La diagonal divide naturaleza y razón, vida urbana - la pequeña que se puede desarrollar en el valle- y campo reverdeciente.

También podemos avanzar en otra hipótesis: si es su vida interior la que aflora. De ser así, aquellas ramas que crecen hacia el cielo reflejan lo único "dinámico" de una mujer pasiva y unida al árbol en sombra y cuerpo.

En otro fotomontaje, Sueños de individuación, publicado en Idilio $\mathrm{n}^{\circ} 23 \mathrm{del}$ 26 de abril de 1949, y que, al igual que al anterior, la autora decidió dejar Sin título, nuevamente se insiste sobre el recurso del árbol. Esta vez la figura femenina no está en la naturaleza, sino que desde el interior de una vivienda, a través de la ventana, mira hacia un árbol cuyas raíces comienzan — según Resta arraigarse al suelo. El consejero dijo al respecto:

Se nace como seres separados, pero no se llega a "individuos", realmente autónomos, sino a través de un proceso de crecimiento de la propia personalidad que nos lleva a ser auténticamente uno mismo, lo que uno debe ser. Esta madurez no se alcanza verdaderamente sino hacia la mitad de la vida, entonces es muy frecuente que se presenten sueños que de algún modo simbolicen esta transición de nuestro ser. En el sueño que comentamos, el símbolo que se presentó fue un árbol —el árbol de la 
vida - que se le apareció a la soñadora descendiendo hacia la tierra, para arraigarse profundamente en ella. Como ya se ha dicho en otras ocasiones, lo vegetal simboliza aquello que crece de modo natural, de acuerdo con un equilibrio interior que lo regula armónicamente. Los árboles son lo que deben ser. Y éste era el mensaje del sueño: la soñadora iba a lograr, después de la intensa inquietud de la primera parte de su vida, la tranquilidad de su verdadero ser, iba a alcanzar la plenitud de su personalidad. (Príamo \& Goretti, 2012: 120, cursiva en el original)

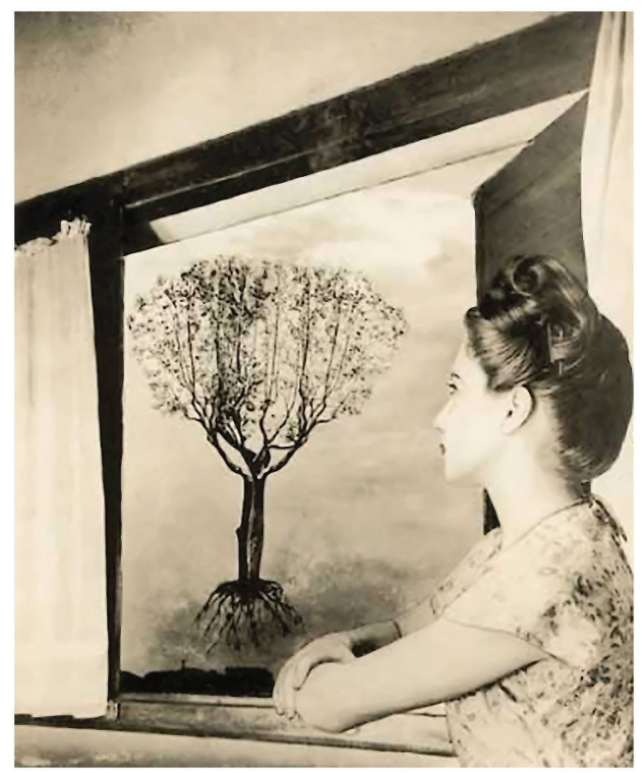

Sueños de individuación, Idilio n² 23, 26 de abril de 1949.

Continuando con la tríada simbólica mujer-naturaleza-fertilidad, la interpretación salvaje de Rest señalaba el descenso del árbol para arraigarse a la tierra como símbolo de madurez. Empleando otras palabras, parece indicar lo que popularmente se suele decir 'ha sentado cabeza'. Sin embargo la mujer permanece en la esfera de lo privado, de lo doméstico, en situación de observar a través de la ventana. Quizás, como plantea Roberta Quance:

$\mathrm{O}$ ¿es más bien que su destino es ser árbol? Y ese árbol, ¿es una diosa caída? (...) Míticamente, los árboles encarnan algo que, en la condición de las mujeres, es a la vez superior e inferior al simple rango mortal. Ese algo, el principio mismo en el que descansan lo sagrado de los árboles, y en general, el significado de todas las diosas madres, es, naturalmente la 
fertilidad. Es algo "alto", en el sentido de que nombra los orígenes de la creación, pero es también "bajo", por cuanto lo que crean las Madres míticas nunca puede dejar el suelo. (Quance, 2000: 145; 148, cursiva en el original)

El personaje femenino aparece coquetamente ataviada observando un árbol cuyo tronco cobra cierto antropomorfismo. Es inevitable recordar la iconografía de Apolo y Dafne, en donde la mujer busca huir de la violación del dios de la razón - paradójicamente- y del equilibrio, invocando el auxilio de los dioses, quienes la transforman en laurel. Esa metamorfosis, tan representada en la historia del arte occidental, pudo haber venido al recuerdo de Stern para este fotomontaje, en donde sueño y realidad se superponen.

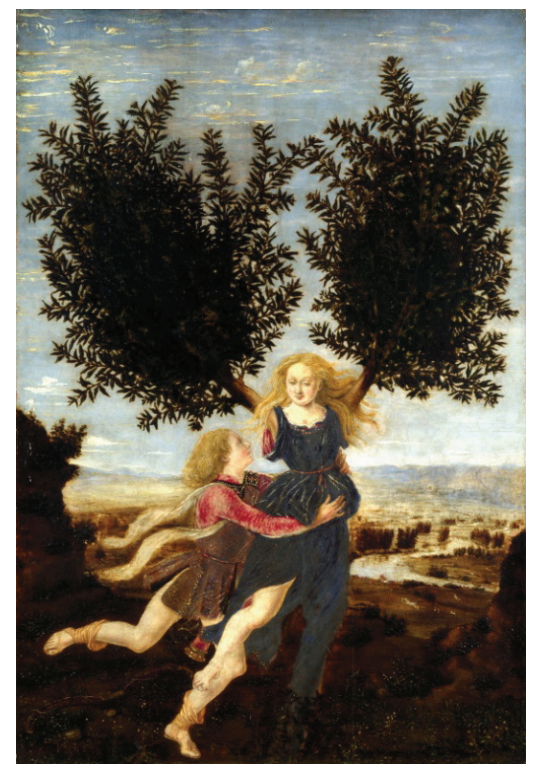

Antonio del Pollaiuolo, Apolo y Dafne, c. 1470-80

Sin embargo, los dos fotomontajes comentados no muestran indicios de una salida alternativa a la domesticidad femenina. ¿Qué otras posibilidades podían tener aquellas mujeres que no querían estar pendientes de la llegada del marido o ser la brújula que guía al hogar? ¿Qué alternativa se presenta para aquellas que simplemente querían vivir sus vidas siendo ellas mismas sus protagonistas?

Los años de los fotomontajes de Stern para Idilio, como ya apuntamos, fueron aquellos en que las mujeres consiguieron su participación ciudadana gracias a la aprobación de la ley 13.010, el 23 de septiembre de 1947, y realizaron 
su primera práctica en las elecciones de 1951. Pero su obra también coincidió cronológicamente con la publicación de El segundo sexo de Simone de Beauvoir -24 de mayo de 1949 - cuyo impacto hizo salir de su letargo al feminismo europeo. Así señaló Marcela Nari respecto a la obra y su recepción argentina:

En París, en 1949, Simone de Beauvoir publicaba los dos tomos de El segundo sexo, habiendo anticipado ya algunos capítulos en Les Temps Modernes. Muy poco tiempo después, debió de haber sido leída en Argentina. En francés, primero; luego, antes de la caída del gobierno peronista, en castellano, a través de la traducción de Pablo Palant para la editorial Psique, distribuida por Siglo XX (1954). El escándalo que produjo en París no parece haberse reproducido en Buenos Aires. (...) Mirando algunas publicaciones de los ' 50 y ' 60 resulta evidente cierta difusión de la obra y figura de Simone de Beauvoir entre determinados círculos políticos, literarios, intelectuales. [Sin embargo, ante una recepción fría, continua diciendo Nari] (...) Gran parte de las tesis sustentadas por Simone de Beauvoir estaban en el debate local. (Nari, 2000: 293-294)

Más allá de que este libro haya sido leído o no por Grete Stern, nos interesa vincular cierto tono irónico de algunos de sus fotomontajes en donde habilita relacionar la cuestión de la inmanencia y la crítica a la naturaleza como destino señalada por Beauvoir en El segundo sexo. En la introducción a la obra, la filósofa se detiene en la categoría de lo Otro, señalando que este concepto siempre se ha enunciado como relativo, a excepción de la mujer. Lo femenino es una alteridad, dice Beauvoir, sin relativismo, es una otredad absoluta que escapa al hecho histórico. Es entonces cuando argumenta que la división de los sexos es un hecho biológico, no un momento histórico. (Beauvoir, 1977: 9-25)

En relación a Stern, resulta interesante poder vincular el concepto de otredad con los fotomontajes de Idilio. La mujer aparece en ellos como lo otro permanente y constante, atada a su biología y sin contingencias que la alteren. Esta inmanencia de lo femenino no fue visibilizada, discutida o cuestionada por el consejero epistolar. Al respecto señala Luis Príamo:

En todos los casos Grete trabajaba sobre la convención de que una mujer había soñado lo que se mostraba en el fotomontaje. Una vez editada, la imagen le servía a Germani para generalizar el problema reflejado en la ilustración -aislamiento, angustia, disconformidad, desorientación- y comentarlo. Así el fotomontaje servía como ejemplo típico bajo un título que el mismo Germani le aplicaba - Sueños de aislamiento, Sueños de angustia, Sueños de disconformidad, Sueños de desorientación- y que luego analizaba con esa perspectiva. (...) La lectura de Germani es, habitualmente, unívoca y taxativa. (...) [ Hecho 
que] termina por cerrarle el paso al efecto de la imagen de Grete, que en sus mejores momentos nos habla con voz seca, breve y sarcástica, que no explica ni exhorta y es por completo ajena a todo sentimentalismo, y que, sobre todo, pone el acento en una crítica axiológica y de costumbres. (Príamo \& Goretti, 2012: 20-21)

Resulta paradójico que en un contexto histórico en el que se estaba debatiendo el lugar político de las mujeres en la sociedad, Grete Stern se detuviera en el mundo privado de quienes escribían sus incomodidades, malestares e incertidumbres. Su mirada va a visibilizar un mundo diferente al del cine y los radioteatros, e inclusive, muy distante al del perfil trazado por la misma revista Idilio.

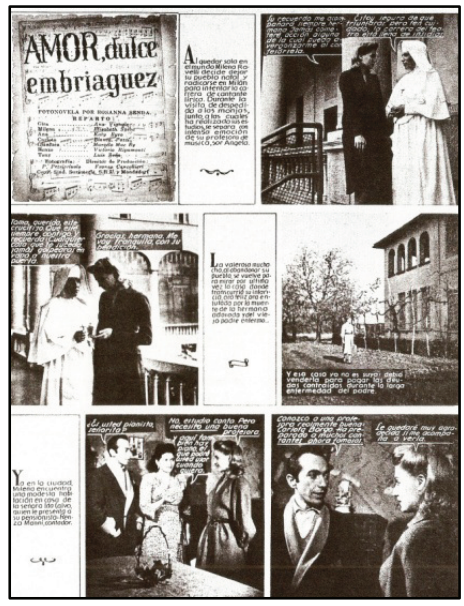

Revista Idilio, $\mathrm{n}^{\circ} 1$, p. 3

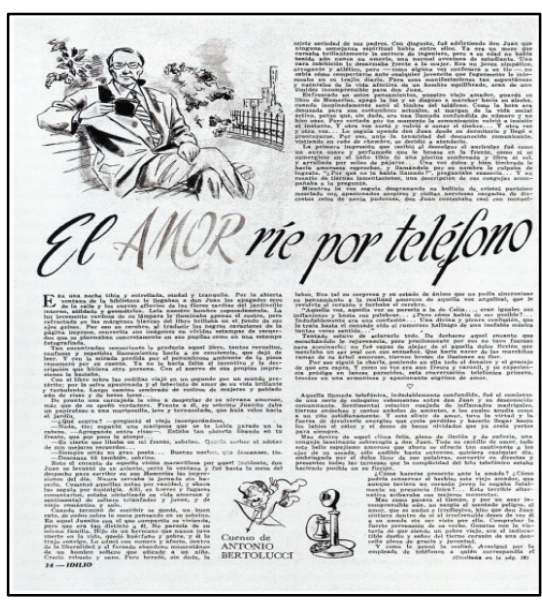

Revista Idilio $\mathrm{n}^{\circ} 55$, p. 14

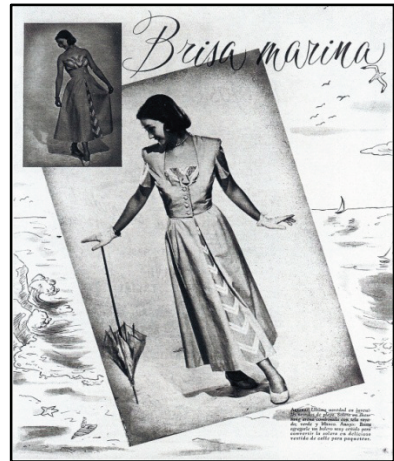

Revista Idilio ${ }^{\circ} 55$, p. 24 
Sin ánimo de extenderme más, aludiré a dos fotomontajes en los que Stern retoma el tema de la maternidad y la institución del matrimonio como razón de ser de la mujer. En El niño en los sueños, Idilio n ${ }^{\circ}$ 10, del 28 de diciembre de 1948, al que la fotógrafa denominó Niño flor, volvió a la tríada mujer-naturalezafertilidad de las piezas ya comentadas. Así interpretó el consejero:

El símbolo del niño, cuando no se refiere directamente a lo maternal, cosa que ocurre, pero no tan frecuentemente como podría creerse, significa que algo nuevo está por acontecer en la personalidad del soñador. "En la anticipación — dice Jung - de una disposición de conciencia que debe producirse cada día". El sueño que comentamos anuncia la feliz superación de un hondo conflicto anímico, que por largo tiempo había torturado a la soñadora. Sobre el fondo de un hermoso paisaje se ofrece una flor (símbolo de belleza y naturalidad), surgiendo de ella un niño (un nuevo despertar, una nueva vida). Para un alma soñadora, este sueño fue como un arco iris después de la tempestad. (Príamo \& Goretti, 2012: 115-116)

Sin embargo, Stern eligió centralizar a la imagen de tal manera que la mano que eleva la flor con el niño en su interior se ubica en el eje visual compositivo. Como si de una mano portando una bandera, tan característica de los carteles de

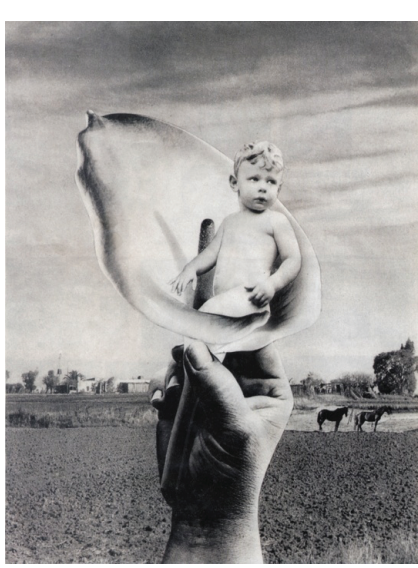
propaganda desarrollados durante la Segunda Guerra Mundial, la mano robusta (¿masculina o femenina?) se erige segura de lo que porta. La línea de horizonte un tanto baja, resalta ese paisaje tradicional de la pampa, con algunos animales, árboles y construcciones.

El niño en los sueños, Idilio $\mathrm{n}^{\circ} 10,28$ de diciembre de 1948 


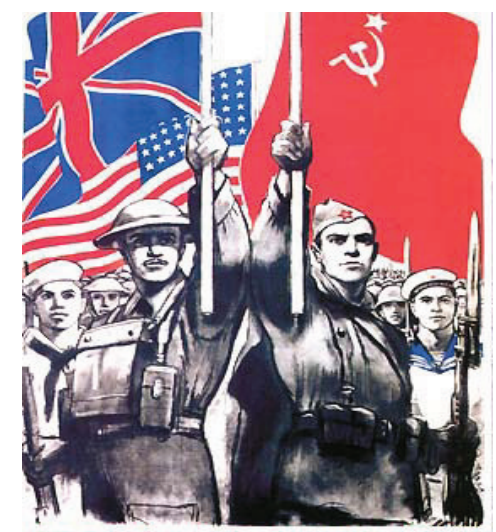

ДА ЗДРАВСТВУЕТ ЕДИНЫЙ ФРОНТ СВОБОДОЛЮБИВЫХ НАРОДОВ ПРОТИв ФАШИСТСКИХ ЗАХВАТЧИКОВ!

Propaganda soviética de la confraternidad

con los aliados occidentales contra el peligro nazi-fascista

La artista eligió una flor sensual y elocuente como la cala, superponiendo al niño en el pistilo para la captura de todas las miradas. Como si de un falo se tratara, pistilo y niño varón está unidos y contenidos por el enorme pétalo a modo de vientre. La artista está jugando con una imagen cuya ambigüedad refiere a la situación vivida por las mujeres de entonces: debatidas entre el deseo y los mandatos, la maternidad podía obturar un camino hacia la libertad que a su vez se hallaba plagado de obstáculos.

En Los sueños de reminiscencias, Idilio $\mathrm{n}^{\circ} 22$ del 19 de abril de 1949, llamado por la fotógrafa Consentimiento, vemos a una jovencita atrapada por la red que le arroja desde su ventana un caballero.

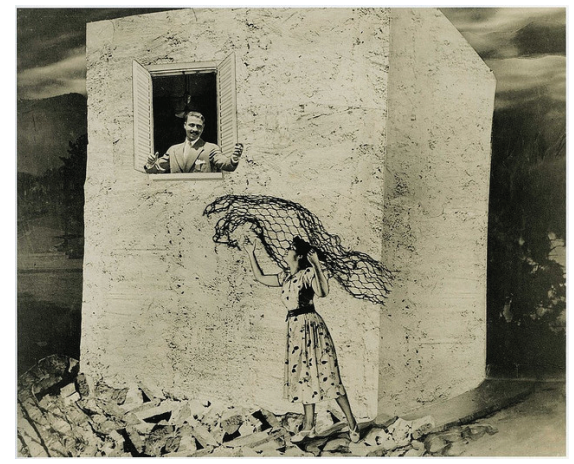

Los sueños de reminiscencias, Idilio $\mathrm{n}^{\circ} 22,19$ de abril de 1949

La casa es un cubo sin puerta, el que a modo de bloque se levanta sobre piedras. Nada hace pensar en un futuro optimista para aquella mujer, quien 
comenzaba una relación siendo cazada y habitando un lugar de encierro. El fondo compositivo dado por un cielo nuboso y un arroyo que se dispone hacia el infinito, son referentes más de un futuro gris que esperanzador. Sin embargo Rest argumentó:

La casa, propia o ajena, es un elemento muy común en los sueños. A menudo ella simboliza la propia persona del soñador, a veces se refiere, en cambio, a la de otros. En muchos casos se la considera un símbolo típicamente femenino. En este sueño, la soñadora vio la casa de su adolescencia - extrañamente transfigurada- y en ella un joven a quien la vinculaban desde largo tiempo lazos de afecto y amistad. Una vez más hallamos aquí cómo el inconsciente revela el verdadero significado de una relación; el sueño indica claramente que esa relación amistosa no era tal y debía situarse en el plano del amor. Pero la soñadora no había advertido todo eso. Ella se ve en el sueño, bailando frente a la casa de la adolescencia - una casa sin puertas y desde cuya única ventana la llama el joven amigo- - . Toda la escena parece significar: "Debes volver a tus años de juventud, y puedes lograrlo sólo a través del llamado de tu amigo, a quien amas”. (Príamo \& Goretti, 2012: 120)

Es evidente la influencia de los cuentos de hadas en los comentarios de Germani: la mujer encuentra la felicidad gracias al amor romántico y al cumplimiento de los mandatos. En muy pocos casos los consejos de Rest fueron osados; por el contrario, la mayoría de las veces buscaron conciliar las molestias de las lectoras, sus expectativas de cambio y sus ansias de proyectos personales, con los roles de madre y esposa que las mujeres debían desempeñar. Mientras tanto, los fotomontajes de Stern dieron paso a una mirada crítica, perspicaz y cuestionadora de los roles impuestos, que en varios casos, poco tuvieron que ver con los comentarios Rest.

Por aquellos años Simone de Beauvoir abrió los ojos advirtiendo que no se nace mujer sino que se aprende a serlo, que la biología no es destino y que la mujer siendo libre, autónoma, como todo ser humano, se descubre y se elige en un mundo en donde los varones la fijan como objeto y la condenan a la inmanencia ${ }^{8}$. Por entonces se emplearon los términos de opresión y frustración al hablar de muchas de las experiencias femeninas. Es en este contexto donde Grete Stern se muestra como una figura fundamental para la crítica a un ideal de domesticidad que lejos de agrietarse, recobraba sus fuerzas.

\footnotetext{
${ }^{8}$ María Teresa López Pardina señala al respecto: "Beauvoir ve en la tesis de Lévi-Strauss ya citada - en las sociedades primitivas las mujeres son un elemento de intercambio entre los grupos de varones - la confirmación de la suya propia: que en toda sociedad patriarcal -y todas las sociedades conocidas lo son - a la mujer no se le permite realizarse como ser humano trascendente que es" (López Pardina, 1998: 168).
} 


\section{REFERENCIAS BIBLIOGRÁFICAS}

Antelo, Raúl (2008), “As Imagens Como Força”, Crítica Cultural, 2: 1-10. http://www.portaldeperiodicos.unisul.br/index.php/Critica_Cultural/article/v iew/117

Barrancos, Dora (2007), Mujeres en la sociedad argentina. Una historia de cinco siglos, Buenos Aires, Sudamericana.

Ben Plotkin, Pablo (2003), Freud en las pampas. Orígenes y desarrollo de una cultura psicoanalítica en la Argentina (1910-1983), Buenos Aires, Sudamericana.

Bertúa, Paula (2008), "Sueños de Idilio: los fotomontajes surrealistas de Grete Stern", Boletín de estética, 6: 7-32.

http://boletindeestetica.com.ar/boletines/Boletin.Estetica.6.pdf

- (2010), "Relatos modernos, centramientos y descentramientos de género. Los Sueños de Grete Stern, Idilio", Mora, 16: 1-15.

-(2012), La cámara en el umbral de lo sensible. Grete Stern y la revista Idilio 1948-1951, Buenos Aires, Biblos.

Constantín, María Teresa y Diana Wechsler (2005), Los surrealistas. Insurrectos, iconoclastas y revolucionarios, Buenos Aires, Longseller.

De Beauvoir, Simone (1977), El segundo sexo. Los hechos y los mitos, Buenos Aires, Siglo XX.

-(1998), El segundo sexo, con presentación de María Teresa López Pardina, Madrid, Cátedra.

De Lauretis, Teresa (1999), Diferencias. Etapas de un camino a través del feminismo, Madrid, horas y Horas.

Devoto, Fernando y Marta Madero (eds.) (1999), Historia de la vida privada en la Argentina, Buenos Aires, Taurus.

Fabris, Annateresa (2009), "O teatro do inconsciente: as fotomontagens de Grete Stern para Idilio", Os sonhos de Grete Stern (cat. expo.), Sâo Paulo, Museu Lasar Segall: 20-37.

Foster, David (2004), “Dreaming in Femenine: Grete Stern's Photomontages and the Parody of Psychoanalysis", Ciberletras, 10.

http://www.lehman.cuny.edu/ciberletras/v10/foster.htm

Frayze-Pereira, João (2009), “Grete e Freud: fotografía e psicoanálise, sonho e intrepretação", Os sonhos de Grete Stern (cat. expo.), Sâo Paulo, Museu Lasar Segall: 38-49.

Gullco, Jorge (1980), “Sencillamente, Grete Stern”, Grete Stern. Fotografía 19271980 (cat. expo.), Buenos Aires, Fundación San Telmo.

Halperín, Paula y Omar Acha (eds.) (2000), Cuerpos, géneros e identidades. Estudios de historia de género en Argentina, Buenos Aires, Ediciones del Siglo. 
Kofman, Sarah (1997), El enigma de la mujer. ¿Con Freud o contra Freud?, Barcelona, Gedisa.

López Pardina, María Teresa (1998), Simone de Beauvoir. Una filósofa del Siglo XX, Cádiz, Servicio de Publicaciones de la Universidad.

Míguez, Eduardo (1999), "Familias de clase media: la formación de un modelo", Historia de la vida privada en la Argentina, Fernando Devoto y Marta Madero (eds.), Buenos Aires, Taurus: 20-45.

Moreno, María (2009), “A câmera desperta”, Os sonhos de Grete Stern (cat. expo.), Sâo Paulo, Museu Lasar Segall: 8-19.

Nari, Marcela (2000), "No se nace feminista, se llega a serlo. Lecturas y recuerdos de Simone de Beauvoir en Argentina, 1950 y 1990", Cuerpos, géneros e identidades. Estudios de historia de género en Argentina, Paula Halperín y Omar Acha (eds.), Buenos Aires, Ediciones del Siglo: 291-299.

Nari, Marcela (2004), Políticas de maternidad y maternalismo político. Buenos Aires (1890-1940), Buenos Aires, Biblos.

Perón, Eva (1951), La razón de mi vida, Buenos Aires, Peuser.

Príamo, Luis y Matteo Goretti (eds.) (2012), Sueños. Fotomontajes de Grete Stern. Serie completa. Edición de la obra impresa en la revista Idilio (1948-1951), Buenos Aires, Fundación Ceppa.

Quance, Roberta Ann (2000), Mujer o árbol. Mitología y modernidad en el arte y la literatura de nuestro tiempo, Madrid, Balsa de la Medusa.

Rossi, Cristina (2012), Jóvenes y modernos de los años 50. En diálogo con la colección Ignacio Pirovano (cat. expo.), Buenos Aires, MAMBA.

Soria, Claudia (2010), “Grete Stern: imágenes del goce femenino”, Mora, 16: 3448.

Soto, Moira (2000), "El rescate de Grete", Página 12, "Las 12", 3 de agosto de 2000. http://www.pagina12.com.ar/2000/suple/las12/00-08-04/nota2.htm

Stern, Grete (2012), “Apuntes sobre fotomontaje”, Sueños. Fotomontajes de Grete Stern. Serie completa. Edición de la obra impresa en la revista Idilio (19481951), Luis Príamo y Matteo Goretti (eds.), Buenos Aires, Fundación Ceppa: 29-33.

Taylor, Brandon (2009), “Al filo de la creación”, Exit, 35: 18-28.

V.V.A.A. (2009), Os sonhos de Grete Stern (cat. expo.), São Paulo, Museu Lasar Segall.

V.V.A.A. (1995), Grete Stern (cat. expo), Valencia, IVAM Centre Julio Gonález.

Vezzetti, Hugo (1999), "Las promesas del psicoanálisis en la cultura de masas", Historia de la vida privada en la Argentina, Fernando Devoto y Marta Madero (eds.), Buenos Aires, Taurus: 173-197.

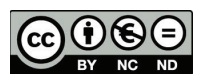

